\title{
Bias Wawancara: Perbedaan Teknik Wawancara (Situational dan Behavioral) dalam Hal Penilaian Wawancara Kerja
}

\author{
Primagitta Hermawati, Ika Rahma Susilawati, Selly Dian Widyasari \\ primagitta@gmail.com \\ Jurusan Psikologi, Universitas Brawijaya, Malang, Indonesia
}

\begin{abstract}
Penelitian ini bertujuan untuk mengetahui perbedaan hasil penilaian wawancara kerja antara kandidat yang diwawancarai dengan teknik situational dengan behavioral. Penelitian ini menggunakan desain between subject yang mana terdapat dua kelompok dan mendapatkan perlakuan yang berbeda. Penelitian ini dilakukan kepada 110 partisipan mahasiswa psikologi Universitas Brawijaya yang telah lulus mata kuliah Psikodiagnostik III (Wawancara). Partisipan dalam eksperimen ini mendapat dua perlakuan, yaitu diberi tontonan video wawancara dengan kandidat yang diwawancarai menggunakan teknik wawancara situational dan video wawancara dengan kandidat yang diwawancarai menggunakan teknik wawancara behavioral. Setelah menonton video, partisipan diminta untuk memberi penilaian terhadap kandidat tersebut. Hasil analisis statistik menggunakan teknik independent sample t-test menunjukan bahwa terdapat perbedaan yang signifikan antara hasil penilaian wawancara kandidat yang diwawancarai dengan teknik wawancara situational dan behavioral, di mana kandidat yang diwawancara dengan teknik situational memperoleh penilaian lebih rendah secara signifikan daripada kandidat yang diwawancarai dengan teknik behavioral $(\mathrm{F}=0.001$, $\mathrm{P}<0.05)$.
\end{abstract}

Kata kunci: bias wawancara; penilaian wawancara; teknik wawancara

\section{Pendahuluan}

Organisasi dapat berjalan dengan baik jika organisasi tersebut mempunyai sumber daya manusia yang sesuai dengan bidang tugasnya (Safaria, Triantoro, \& Nofrans, 2009). Adanya proses rekrutmen dan seleksi yang sesuai dengan prosedur sangat dibutuhkan agar perusahaan mendapatkan karyawan yang sesuai dengan kriteria yang diinginkan. Sementara itu, proses rekrutmen dan seleksi dianggap memenuhi prosedur adalah ketika proses tersebut berjalan secara teratur dan bersifat objektif serta dapat membawa implikasi dalam pencapian tujuan perusahaan (Handoko, 2008). Mangkuprawira (2002) menyatakan bahwa salah satu tahapan seleksi dan rekrutmen yang selalu digunakan dalam perusahaan adalah tahapan seleksi menggunakan metode wawancara.

Menurut Hasibuan (2001), wawancara kerja digunakan untuk mengevaluasi diterima atau tidaknya seorang pelamar dengan percakapan langsung. Pewawancara yang berpengalaman dan jeli akan dapat menggali kemampuan seorang pelamar. Wawancara kerja telah menjadi salah satu metode seleksi yang paling banyak digunakan dalam 100 tahun terakhir (Macan, 2009). Menurut Huffcutt dan Culbertson (2010), wawancara kerja menjadi salah satu metode yang digunakan untuk menilai pelamar kerja serta langkah pengambilan keputusan dalam mendapatkan calon karyawan yang akan diperkerjakan. Proses pengambilan keputusan untuk mendapatkan calon karyawan dalam wawancara kerja ini mengarah pada penilaian wawancara kerja yang dilakukan (Levashina, Hartwell, Morgeson, \& Campion, 2013). Penilaian wawancara ini biasanya dilakukan melalui pemeringkatan atau yang lebih dikenal dengan rating interviu. Rating interviu merupakan pemeringkatan yang dilakukan oleh pewawancara dalam menilai kandidat 
dengan standar yang telah ditetapkan (Barrick, Shaffer, \& Degrassi, 2009).

Penilaian atau rating interviu dalam wawancara kerja mempunyai beberapa faktor kendala baik dari pewawancara maupun terwawancara. Eder dan Harris (2006) menyatakan bahwa terdapat kelebihan dan kekurangan dalam melakukan penilaian wawancara kerja, di antaranya adanya bias penilaian yang dilakukan tim penilai. Bias terjadi ketika seseorang mengungkapkan gambaran yang salah atau keliru tentang keadaan sebenarnya (Wirawan, 2012). Bias dalam wawancara bisa dilakukan oleh kedua belah pihak, yaitu pihak terwawancara dan pewawancara. Bias yang bisa terjadi pada terwawancara adalah responden tidak menjawab pertanyaan yang diberikan pewawancara dengan jujur. Selain itu, responden yang sebenarnya tidak memahami isi pertanyaan tetapi enggan bertanya atau melakukan klarifikasi juga dapat menghasilkan bias pada suatu wawancara (Leary \& Kowalski, 1990).

Bias wawancara yang timbul selain karena faktor pewawancara dan terwawancara dapat terjadi karena pengaruh faktor situasional. Faktor situasional mencakup aspek tempat, waktu, dan teknik wawancara yang digunakan (Zajonc, 1984). Terkait aspekaspek dalam faktor situasional tersebut, peneliti akan menggunakan teknik wawancara sebagai fokus dalam penelitian ini. Hal ini diperkuat oleh Huffcutt, Roth, Conway, dan Klehe (2004) yang menyatakan bahwa teknik wawancara sangat berpengaruh dalam faktor situaional karena dapat melihat sikap dan jawaban dari calon pelamar serta tidak jarang dapat menimbulkan bias (Hadi, 2004). Adapun teknik wawancara tersebut dibagi menjadi dua jenis, yaitu teknik wawancara situational dan teknik wawancara behavioral (Klehee, Latham, Saari, Pursell, \& Campion, 1980). Teknik wawancara situational dan wawancara behavioral telah muncul sebagai format utama untuk melakukan wawancara terstruktur modern (Arvey \& Campion, 1982).

Masing-masing teknik wawancara memiliki tujuan tersendiri. Tujuan utama dari teknik wawancara behavioral menurut Arvey dan Campion (1982) adalah untuk mengumpulkan informasi dari calon pelamar tentang perilaku mereka yang sebenarnya selama pengalaman masa lalu. Sementara menurut Campion, Campion dan Palmer (1997), pertanyaan-pertanyaan dalam teknik wawancara situational didasarkan pada perilaku yang berorientasi pada masa depan. Tujuan dari teknik pertanyaan wawancara situational adalah untuk memberikan pertanyaan kepada individu ketika berada dalam situasi-situasi tertentu.

Berdasarkan uraian di atas, tujuan dari penelitian ini adalah ingin mengetahui perbedaan penilaian hasil kandidat yang diwawancarai menggunakan teknik wawancara situational dengan behavioral. Peneliti berhipotesis bahwa ada perbedaan hasil penilaian kandidat yang diwawancarai menggunakan teknik situational dengan behavioral.

\section{Metode}

\section{Desain penelitian}

Metode penelitian yang digunakan dalam penelitian ini adalah metode penelitian eksperimen. Adapun jenis desain eksperimental yang digunakan dalam penelitian ini adalah desain between-subjects, di mana terdapat dua kelompok partisipan yang akan mendapatkan perlakuan yang berbeda. 


\section{Partisipan}

Partisipan yang digunakan dalam penelitian ini merupakan mahasiswa Jurusan Psikologi, Universitas Brawijaya dengan kriteria yaitu tergabung di angkatan 2013 atau sebelumnya. Partisipan juga diharuskan telah lulus mata kuliah Psikodiagnostik III (wawancara). Jumlah partisipan pada penelitian ini adalah 110 mahasiswa.

\section{Instrumen penelitian}

Formulir penilaian wawancara

Formulir penilaian wawancara berisi mengenai kompetensi-kompetensi yang menjadi penilaian wawancara dan rekomendasi aksi sebagai bahan tambahan evaluasi setelah penilaian.

Penilaian wawancara berisi penilaian berdasarkan kompetensi yang telah ditetapkan dan dilakukan dengan cara memberikan pemeringkatan (rating) untuk menilai kesesuaian kandidat dengan standar yang telah menjadi persyaratan. Penilaian tersebut didasarkan pada delapan kompetensi yang digunakan yang mewakili kompetensi pengelolaan kerja (conceptual thinking, continuous improvement, dan managing quality), kompetensi pengelolaan personalia (team work, communication, dan leadership skill), serta kompetensi pengelolaan diri (integrity dan drive for excellent). Kompetensi tersebut akan dinilai dengan rentang 6 poin mulai dari poin 0 yang bermakna sangat kurang sampai dengan poin 6 yang berarti sangat baik.

Selain itu, terdapat juga pilihan rekomendasi aksi pada lembar penilaian wawancara kerja. Rekomendasi aksi adalah rekomendasi mengenai keputusan akhir dari pewawancara terhadap kandidat berdasarkan hasil evaluasi penilaian wawancara kerja.
Terdapat tiga pernyataan dalam rekomendasi aksi, yaitu "disarankan", "dipertimbangkan", dan "tidak disarankan".

\section{Video Wawancara}

Video wawancara berisi proses tanya jawab antara pewawancara dan pelamar fiktif. Terdapat dua video yang digunakan pada penelitian ini. Video pertama berisi pertanyaan-pertanyaan menggunakan teknik wawancara situational sedangkan pada video kedua berisi pertanyaan-pertanyaan yang menggunakan teknik wawancara behavioral. Jawaban pertanyaan pada teknik wawancara situational dan teknik wawancara behavioral pada intinya merupakan jawaban yang sama, hanya saja pada teknik wawancara situational dibuat seolah-olah merupakan sesuatu yang akan dilakukan oleh pelamar sedangkan pada teknik wawancara behavioral dibuat seolaholah merupakan pengalaman dari pelamar. Pada kedua video tersebut, hanya pemeran yang berperan sebagai pelamar yang diperlihatkan kepada partisipan, sedangkan untuk pewawancara akan diperdengarkan suaranya saja sehingga partisipan penelitian dibuat seolah-olah sedang berhadapan langsung dengan pelamar saat melihat video tersebut.

\section{Manipulation check}

Manipulation check dibutuhkan untuk mengetahui apakah perubahan perilaku atau sikap yang terjadi pada partisipan benar-benar dikarenakan perlakuan yang diberikan atau terdapat faktor lain yang menyebabkan hal tersebut terjadi. Manipulation check ini berisi pernyataan, "Menurut saya, teknik yang digunakan dalam wawancara ini adalah..." serta memiliki dua pilihan jawaban, yaitu " 1 " (teknik situational) dan " 2 " (teknik behavioral). 


\section{Standar Kompetensi Kunci}

Standar Kompetensi Kunci (SKK) merupakan standar yang dibuat oleh peneliti yang didasarkan pada kriteria rekomendasi perusahaan dan umumnya mengacu pada kamus kompetensi. SKK ini dibuat sebagai dasar setiap jawaban kandidat dari teknik situational maupun behavioral. SKK ini juga digunakan dalam standar kompetensi persyaratan minimal pada penialaian formulir wawancara.

\section{Hasil}

\section{Gambaran umum partisipan}

Partisipan penelitian adalah 110 mahasiswa. Partisipan tersebut merupakan mahasiswa Jurusan Psikologi Universitas Brawijaya angkatan 2012-2013 yang telah lulus mata kuliah Psikodiagnostik III (wawancara). Usia partisipan memiliki rentang dari 19-22 tahun. Partisipan kemudian dibagi menjadi dua kelompok, yaitu kelompok teknik wawancara situational sebanyak 55 orang dan kelompok teknik wawancara behavioral sebanyak 55 orang (selengkapnya di Tabel 1).

Tabel 1

Karakteristik partisipan

\begin{tabular}{|c|c|c|c|}
\hline \multicolumn{2}{|c|}{ Karakteristik Partisipan } & \multirow{2}{*}{$\begin{array}{c}\text { Jumlah } \\
20\end{array}$} & \multirow{2}{*}{$\begin{array}{c}\text { Persentase } \\
18.18 \%\end{array}$} \\
\hline Jenis Kelamin & Laki-laki & & \\
\hline & Perempuan & 90 & $81.81 \%$ \\
\hline \multirow[t]{4}{*}{ Usia } & 20 & 26 & $23.64 \%$ \\
\hline & 21 & 62 & $56.36 \%$ \\
\hline & 22 & 19 & $17.27 \%$ \\
\hline & 23 & 3 & $2.73 \%$ \\
\hline \multirow[t]{2}{*}{ Angkatan } & 2012 & 22 & 20 \\
\hline & 2013 & 88 & 80 \\
\hline \multicolumn{2}{|c|}{ Total Partisipan } & 110 & \\
\hline
\end{tabular}

\section{Manipulation check}

Berdasarkan hasil analisis deskriptif setelah dilakukan manipulation check, pada kelompok teknik wawancara situational, 76.36\% partisipan memilih teknik wawancara situational dan sebanyak $23.64 \%$ mengatakan bahwa teknik wawancara tersebut adalah teknik wawancara behavioral. Pada kelompok teknik wawancara behavioral, sebanyak $12.72 \%$ partisipan mengatakan bahwa teknik yang ditampilkan adalah teknik wawancara situational dan sebanyak $87.27 \%$ partisipan mengatakan sebaliknya yaitu teknik behavioral. Hal ini menunjukkan bahwa partisipan paham dengan teknik wawancara apa yang sedang ditayangkan di hadapan mereka.

Tabel 2

Analisis deskriptif hasil manipulation check

\begin{tabular}{|c|c|c|c|}
\hline \multicolumn{2}{|l|}{ Pernyataan } & $\begin{array}{c}\text { Teknik } \\
\text { Situational }\end{array}$ & $\begin{array}{c}\text { Teknik } \\
\text { Behavioral }\end{array}$ \\
\hline $\begin{array}{l}\text { "Menurut } \\
\text { saya teknik } \\
\text { yang }\end{array}$ & KTS* & $\begin{array}{c}42 \\
(76.36 \%)\end{array}$ & $\begin{array}{c}13 \\
(23.64 \%)\end{array}$ \\
\hline $\begin{array}{l}\text { dalam } \\
\text { wawancara } \\
\text { ini adalah..." }\end{array}$ & KTB** & $\begin{array}{c}7 \\
(12.72 \%)\end{array}$ & $\begin{array}{c}48 \\
(87.7 \%)\end{array}$ \\
\hline
\end{tabular}

\section{Hasil uji hipotesis}

Pengujian hipotesis dilakukan dengan cara membandingkan rata-rata penilaian hasil teknik wawancara pada kelompok teknik situational dan kelompok teknik wawancara behavioral (Tabel 3). Dari hasil uji perbedaan formulir penilaian wawancara kerja diketahui bahwa terdapat nilai signifikasi sebesar 0.001 $(\mathrm{p}<0.05)$ menunjukan bahwa H0 ditolak. Kemudian, didapatkan nilai rerata KTS sebesar 32.01 dan nilai rerata KTB sebesar 35.67. Maka selanjutnya dapat disimpulkan bahwa terdapat perbedaan penilaian wawancara yang sangat signifikan antara KTS dan KTB di mana KTS memperoleh penilaian lebih rendah secara signifikan dibanding KTB. 
Tabel 3

Hasil uji perbedaan penilaian wawancara kerja

\begin{tabular}{lccccc}
\hline & \multirow{2}{*}{ Sig. } & \multicolumn{2}{c}{ KTS } & \multicolumn{2}{c}{ KTB } \\
\cline { 3 - 6 } & & Mean & SD & Mean & SD \\
\hline $\begin{array}{l}\text { Rating } \\
\text { interviu }\end{array}$ & $0.001 *$ & 32.01 & 4.16 & 35.67 & 4.00 \\
\hline *sig<0.05; **sig $<0.01 ; * * *$ sig $<0.0001$ & &
\end{tabular}

\section{Hasil analisis rekomendasi ahli}

Tabel 4

Hasil rekomendasi ahli

\begin{tabular}{ccccc}
\hline \multirow{2}{*}{ Teknik } & \multicolumn{4}{c}{ RA } \\
\cline { 2 - 4 } & Disarankan & $\begin{array}{c}\text { Dipertim- } \\
\text { bangkan }\end{array}$ & $\begin{array}{c}\text { Tidak } \\
\text { disarankan }\end{array}$ & \\
\hline Behavioral & 50 & 4 & 1 & 55 \\
\hline Situational & 44 & 9 & 2 & 55 \\
\hline Total & 94 & 13 & 3 & 110 \\
\hline
\end{tabular}

Setelah dilakukan uji Chi-Square maka didapatkan nilai Chi-Square sebesar 2.639 dengan tingkat signifikansi lebih besar dari pada alpha (0.267>0.05). Kesimpulan dari hasil ini adalah tidak ada perbedaan yang signifikan antara rekomendasi aksi kandidat yang diwawancarai menggunakan teknik wawancara situational dengan behavioral sebagaimana dapat dilihat selengkapnya pada Tabel 4.

\section{Hasil analisis perbandingan teknik wawancara dengan SKK}

Pada analisis ini, teknik wawancara akan dibandingkan dengan Standar Kompetensi Kunci (SKK). SKK merupakan standar yang digunakan dalam level kompetensi yang terdapat dalam video wawancara. SKK juga dijadikan sebagai acuan pewawancara dalam memberikan penilaian pada formulir wawancara. Tabel 5 membandingkan antara kelompok situational dan kelompok behavioral dengan SKK. Perbandingan tersebut menunjukan bahwa teknik situational memiliki selisih 7.18 dan teknik behavioral memiliki selisih 8.67 jika dibandingkan dengan SKK sehingga dapat disimpulkan bahwa kedua teknik wawancara tersebut menunjukkan perbedaan yang signifikan jika dibandingkan dengan Standar Kompetensi Kunci (SKK).

Tabel 5

Perbandingan teknik wawancara dengan SKK

\begin{tabular}{lccccc}
\hline & \multirow{2}{*}{ Sig. } & \multicolumn{4}{c}{ SKK } \\
\cline { 3 - 6 } & & Mean & SD & Mean & SD \\
\hline $\begin{array}{l}\text { Teknik } \\
\text { Situational }\end{array}$ & 0.000 & 32.18 & 4.13 & 27.00 & 0.00 \\
\hline $\begin{array}{l}\text { Teknik } \\
\text { Behavioral }\end{array}$ & 0.000 & 35.67 & 4.00 & 27.00 & 0.00 \\
\hline
\end{tabular}

\section{Hasil analisis tambahan komponen penilaian wawancara kerja}

Pengujian kompetensi penyelia (supervisor) HRD (Human Resources Department) dilakukan dengan cara membandingkan rerata delapan nilai kompetensi yang ada pada kelompok teknik wawancara situational (KTS) dan kelompok teknik wawancara behavioral (KTB) seperti yang dapat dilihat pada Tabel 6 .

Tabel 6

Hasil uji beda komponen penilaian wawancara kerja

\begin{tabular}{|c|c|c|c|c|c|}
\hline & \multirow{2}{*}{ Sig. } & \multicolumn{2}{|c|}{ KTS } & \multicolumn{2}{|c|}{ KTB } \\
\hline & & Mean & SD & Mean & SD \\
\hline $\begin{array}{l}\text { Conceptual } \\
\text { Thinking }\end{array}$ & $0.039 *$ & 3.94 & 0.91 & 4.34 & 1.09 \\
\hline $\begin{array}{l}\text { Continuous } \\
\text { Improvement }\end{array}$ & $0.01 *$ & 3.60 & 0.93 & 4.18 & 1.16 \\
\hline $\begin{array}{l}\text { Managing } \\
\text { Quality }\end{array}$ & 0.055 & 4.10 & 0.85 & 4.43 & 0.91 \\
\hline Team Work & $0.000^{*}$ & 4.25 & 0.77 & 4.83 & 0.89 \\
\hline Communication & 0.131 & 4.01 & 0.87 & 4.30 & 1.12 \\
\hline $\begin{array}{l}\text { Leadership } \\
\text { Skill }\end{array}$ & $0.016^{*}$ & 4.07 & 0.83 & 4.49 & 0.95 \\
\hline Integrity & $0.005^{*}$ & 3.98 & 0.97 & 4.47 & 0.83 \\
\hline $\begin{array}{l}\text { Drive for } \\
\text { Excellent }\end{array}$ & $0.000 *$ & 4.03 & 0.85 & 4.60 & 0.78 \\
\hline
\end{tabular}

\footnotetext{
$* \operatorname{sig}<0.05 ; * * \operatorname{sig}<0.01 ; * * * \operatorname{sig}<0.001$
} 
Berdasarkan analisis perbandingan pada masing-masing kompetensi untuk HRD supervisor, terdapat perbedaan yang signifikan $(\mathrm{p}<0.05)$ antara hasil penilaian wawancara teknik situational dan teknik wawancara behavioral dalam kaitannya dengan kompetensi conceptual thinking, continuous improvement, team work, leadership skill, integrity, dan drive for excellent. Sementara itu, pada dua kompetensi lainnya, yaitu managing quality dan communication, hasil yang ditunjukkan menyatakan bahwa tidak terdapat perbedaan yang signifikan $(p>0.05)$ antara hasil penilaian wawancara teknik situational dan teknik wawancara behavioral.

\section{Diskusi}

Pengujian hipotesis menunjukkan bahwa terdapat perbedaan yang signifikan antara hasil penilaian wawancara pada teknik wawancara situational dan teknik wawancara behavioral. Hal ini berarti bahwa kandidat yang diwawancara menggunakan teknik situational mendapatkan nilai lebih rendah daripada kandidat yang diwawancarai menggunakan teknik behavioral. Hal ini dapat terjadi karena teknik wawancara behavioral memiliki efektivitas yang lebih dalam mengungkap kandidat dibandingkan teknik wawancara situational (Huffcut, dkk., 2001). Pernyataan tersebut didukung pula oleh hasil rekomendasi aksi, di mana teknik wawancara behavioral memang mendapat rekomendasi "disarankan" lebih banyak daripada teknik wawancara situational.

Berdasarkan hasil rekomendasi aksi, diketahui bahwa pada partisipan yang diwawancarai dengan teknik wawancara behavioral mendapatkan rekomendasi "disarankan" lebih banyak daripada partisipan yang diwawancarai dengan teknik wawancara situational, namun selisih hasil penilaian antara kedua teknik wawancara tersebut tidak terpaut jauh. Hal ini dapat disimpulkan bahwa partisipan pada kedua teknik ini sama-sama mampu untuk diajukan sebagai kandidat yang "disarankan" berdasarkan hasil analisis menggunakan uji Chi-square yang menyatakan bahwa tidak ada perbedaan yang signifikan antara rekomendasi aksi kandidat yang diwawancarai menggunakan teknik wawancara situational dengan teknik wawancara behavioral.

Teknik wawancara behavioral menurut Janz (Huffcut, dkk., 2001) merupakan jenis teknik wawancara di mana pewawancara berusaha untuk mencari informasi mengenai pengalaman di masa lalu (actual incidents) dari kandidat. Berbeda dengan teknik wawancara behavioral, Latham, dkk. (1980) menjelaskan bahwa pada teknik wawancara situational, pewawancara memberikan pertanyaan yang bersifat prediksi (Huffcut, dkk., 2001). Perbedaan tersebut tentunya dapat menyebabkan lebih tingginya penilaian pada teknik wawancara behavioral karena pewawancara lebih mempercayai kejadian yang sebenarnya (actual incidents) daripada jawaban yang bersifat prediksi pada teknik wawancara situational. Hal ini bisa terlihat bahwa adanya bias yang muncul pada teknik behavioral lebih tinggi (Klehe \& Latham, 2006).

Tingginya bias pada teknik behavioral ini terjadi karena teknik wawancara tersebut dapat menggali pengalaman masa lalu kandidat sehinggga apa yang diceritakan tersebut merupakan apa yang pernah dialaminya (Klehe \& Latham, 2006). Ketika seorang pewawancara dapat mengumpulkan informasi lebih banyak tentang pengalaman masa lalu, maka tidak menutup kemungkinan akan terjadi keloggaran dalam memberikan 
penilaian. Hal ini dapat pula dikaitkan dengan teori trustworthiness (Myers \& Hansen, 2006) yang mengatakan bahwa terdapat karakteristik penting untuk memahami kepercayaan terkait penggambaran atau pengambilan informasi dari pengalaman sebelumnya. Pengalaman dan kinerja sebelumnya tersebut membuat penilai cenderung memberikan evaluasi yang lebih positif atau lebih tinggi terhadap kompetensi kandidat. Hal ini selaras dengan pernyataan Alarcon, Lyons, \& Christensen (2016) bahwa adanya kepercayaan tersebut ditandai dengan kecenderungan untuk melihat individu dari segi kemampuan dan integritas, yang berkaitan dengan menghadapi situasi atau tugas yang diberikan sehingga dapat menimbulkan kepercayaan dan kebenaran pada penilai dalam individu tersebut.

Perbandingan rerata penilaian SKK (Standar Kompetensi Kunci) dengan kedua teknik wawancara menunjukkan bahwa keduanya memiliki perbedaan yang signifikan. Hal ini berarti bahwa rerata nilai teknik wawancara behavioral dan teknik wawancara situational memiliki selisih yang lebih besar dengan SKK (Standar Kompetensi Kunci), di mana hasil penilaian terhadap kandidat dengan teknik wawancara behavioral memiliki selisih yang lebih tinggi dibanding hasil penilaian terhadap kandidat dengan teknik wawancara situational. Teknik wawancara behavioral memiliki bias yang lebih besar jika dibandingkan dengan teknik wawancara situational, sehingga dari hasil penelitian ini maka teknik wawancara yang rendah akan bias dan baik digunakan dalam manfaat praktis adalah teknik wawancara situational.

Wawancara sendiri merupakan salah satu metode perekrutan yang memang sangat rentan terhadap bias. Hal tersebut dikarenakan proses pengambilan keputusan untuk merekrut kandidat didasarkan pada informasi yang terbatas untuk dapat menilai pelamar kerja yang merupakan orang asing, serta menuntut pengambilan keputusan yang cepat dalam waktu yang relatif singkat (Bendick \& Nunes, 2012). Pada pengambilan keputusan ini, penilai biasanya akan mempertimbangkan karakteristik seperti gender, etnis, jenis kelamin, atau pengalaman masa lalu. Karakteristik tersebut digunakan untuk mengambil informasi yang tersimpan di memori otak manusia untuk menyambungkannya dengan kemungkinan perilaku yang sama terhadap orang asing atau kandidat tersebut (MacGarty, Yzerbyt, \& Spears, 2002).

Penelitian selanjutnya diharapkan mampu untuk lebih mempertimbangkan faktor-faktor lain terutama dari segi partisipan (yang bertindak seolah-olah menjadi pewawancara). Partisipan pada penelitian ini memiliki rentang usia antara 19-23 tahun. Partisipan seharusnya diberikan pembekalan metode atau pelatihan mengenai materi wawancara dan kompetensi yang akan digunakan dalam formulir penilaian wawancara. Hal tersebut berguna agar mahasiswa yang akan menjadi partisipan dapat memiliki pemahaman dan kemampuan wawancara yang lebih baik. Jika pada penelitian ini digunakan kategori partisipan yang sama, maka pada penelitian selanjutnya sebaiknya mempertimbangkan karakteristik partisipan semisal usia, jenis kelamin, angkatan, dan nilai mata kuliah Psikodiagnostik III (wawancara). Selain itu, akan lebih pula baik jika pada penelitianpenelitian selanjutnya dilakukan analisis terhadap faktor-faktor yang dapat mempengaruhi hasil penilaian wawancara dari sisi situasi yaitu, informasi pekerjaan, informasi pelamar, serta waktu pengambilan 
keputusan (Mangkuprawira, 2002).

Hasil uji hipotesis menunjukkan bahwa (H1) diterima. Hal ini dapat disimpulkan bahwa terdapat perbedaan dalam hasil penilaian wawancara kerja kandidat yang menggunakan teknik wawancara behavioral dan teknik wawancara situational, di mana kandidat yang diwawancarai dengan teknik behavioral memeroleh penilaian lebih tinggi daripada kandidat yang diwawancarai dengan teknik situational. Hal ini dapat terjadi karena teknik wawancara behavioral dapat menggali pengalaman masa lalu kandidat, sehinggga apa yang diceritakan tersebut merupakan apa yang pernah dialaminya sehingga memungkinkan untuk timbulnya bias (Klehe \& Latham, 2006). Ketika seorang pewawancara dapat mengumpulkan informasi lebih banyak tentang pengalaman masa lalu, maka kemungkinan akan terjadi keloggaran dalam memberikan penilaian. Hal ini berkaitan dengan teori trustworthiness (Mayers, 1955) yang mengatakan bahwa penggambaran atau pengambilan informasi dari pengalaman sebelumnya dapat menimbulkan kepercayaan.

Hasil uji rekomendasi aksidengan menggunakan uji Chi-Square menunjukan perolehan angka sebesar 2.639. Dengan taraf signifikansi (0.267>0.05), maka dapat disimpulkan bahwa tidak ada perbedaan yang signifikan antara rekomendasi aksi kandidat yang diwawancarai menggunakan teknik wawancara situational dengan teknik wawancara behavioral. Hasil analisis perbandingan teknik wawancara dengan SKK (Standar Kompetensi Kunci) terdapat perbedaan hasil yang signifikan antara penilaian teknik wawancara dengan SKK. Hal ini menunjukkan bahwa rerata nilai teknik wawancara behavioral dan teknik wawancara situational memiliki selisih yang lebih besar dengan SKK, di mana hasil penilaian terhadap kandidat dengan teknik wawancara behavioral memiliki selisih yang lebih tinggi dibanding hasil penilaian terhadap kandidat dengan teknik wawancara situasional.

Hasil analisis kompetensi menunjukkan bahwa terdapat perbedaan yang signifikan antara hasil penilaian wawancara. Terdapat enam kompetensi yaitu conceptual thinking, continuous improvement, team work, leadership skill, integrity, dan drive for excellent yang memiliki perbedaan yang signifikan antara kelompok wawancara teknik behavioral daripada kelompok wawancara teknik situational. Pada kompetensi managing quality dan communication, tidak terdapat perbedaan nilai yang signifikan pada kedua kelompok.

\section{Daftar Pustaka}

Alarcon, M. G., Lyons, B. J., \& Christensen, C. J. (2016). The effect of propensity to trust and familiarity on perceptions of trustworthiness over time. Personality Indivudual Differences, 94, 309-315.

Arvey, R. D., \& Campion, J. E. (1982). The employment interview: a summary and review of recent research. Personnel Psychology, 35.

Barrick, M. R., Shaffer, J. A., \& Degrassi, S. W. (2009). What you see may not be what you get: relationships among selfpresentation tactics and ratings of interview and job performance. Journal of Applied Psychology, 94(6), 13941411.

Bendick, M. J., \& Nunes, A. P. (2012). Developing the research basis for controlling bias in hiring. Journal of 
Social Issues, 68(2), 238-262.

Campion, M. A., Campion, J. E., \& Palmer, D. K. (1997). A review structure in the selection interview. Personel Psychology, 50, 655-702

Eder, R., \& Haris, D. (2006). Managing Quality. Massachusetts: AddisonWesley Publishing Company Inc.

Handoko, T. (2008). Manajemen Personalia dan Sumber Daya Manusia. BPFE: Yogyakarta

Hasibuan, M. (2001). Manajemen Sumber Daya Manusia. Jakarta: Bumi Aksara.

Huffcut, A. I., Weekley, J. A., Wiesner, W. H., \& Degroot, T. G. (2001). Comparison of situational and behavior description interview question for higher-level positions. Personnel Psychology, 54(3), 619-644.

Hufcutt, A. I., \& Culbertson, T. A. (2010). The effect of applicant influence tactics on recruiter perceptions of fit and hiring recommendations: a field study. Journal of Applied Psychology, 89(4), 622-632.

Huffcutt, A. I., Roth, P. L., Conway, J. M., \& Klehe, U. C. (2004). The impact of job complexity and study design on situational and behavior description interview validity. International Journal of Selection and Assessment, 12(3), 262273.

Klehe, U. C., \& Latham, G. (2006). What would you do-really or ideally? Contructs underlying the behavior description interview and the situational interview in predicting typical versus maximum performnace. Human performance, 19(4), 357-382.

Leary, M. R., \& Kowalski, P. (1990).
Introduction to Behavioral Research Methods. Belmont, CA: Wadsworth.

Levashina, J., Hartwell, C. J., Morgeson, F. P., \& Campion, M. A (2013). The stuctured employment interview: narrative and quantitative review of the research literature: Personel Psychology, 67(1), 241-293.

Macan, T. (2009). The employment interview: a review of current studies and directions for future research. Human Resources Management Review, 19(3), 203-218.

MacGarty, C., Yzerbyt, V. Y., \& Spears, R. (2002). Stereotypes as Explanations: The Formation of Meaningful Beliefs about Social Groups. Cambridge: Cambridge University Press.

Mangkuprawira, S. (2002). Manajemen Sumber Daya Manusia Strategik. Jakarta: Ghalia Indonesia.

Myers, A., \& Hansen, C. H. (2006). Experimental Psychology 6th Edition. Belmont, CA: Wadworth Inc.

Zajonc, R. B. (1984). On the primacy of affect. American Psychologist, 39(2), 117-124.

Wirawan. (2012). Evaluasi Kinerja sumber Daya Manusia: Teori Aplikasi dan Penelitian. Jakarta: Salemba Empat. 